\title{
Hubungan Batugamping Formasi Sentolo dan Breksi Vulkanik Kulon Progo: Sebuah Koreksi Stratigrafi Studi Kasus di Daerah Wonotopo, Kecamatan Gebang, Kabupaten Purworejo, Jawa Tengah
}

\author{
Sari Bahagiarti Kusumayudha a), Delvianus Kaesmetan, Heru Sigit Purwanto \\ Jurusan Teknik Geologi, Universitas Pembangunan Nasional "Veteran" Yogyakarta \\ Jl. SWK 104 Condongcatur Yogyakarta 55285 \\ ${ }^{a)}$ Email Korespondensi: saribk@upnyk.ac.id
}

\begin{abstract}
ABSTRAK
Fisiografi Jawa Tengah oleh Van Bemmelen (1949) dibagi menjadi enam zona, yaitu Dataran Aluvial Utara Jawa, Antiklinorium Serayu Utara, Kubah dan Punggungan pada Zona Depresi Tengah, Zona Depresi Tengah dengan Gunung-gunung Api Kuarter, dan Pegunungan Selatan. Daerah Wonotopo dan sekitarnya termasuk di dalam Kubah Kulon Progo. Litostratigrafi di daerah ini dari umur tua ke muda, secara berturut-turut adalah Formasi Nanggulan, Formasi Kaligesing, Formasi Dukuh, Formasi Jonggrangan, Formasi Sentolo, serta endapan gunung api Kuarter dan endapan aluvial. Pada umumnya para peneliti terdahulu (Van Bemmelen, 1949; Pringgoprawiro dan Riyanto, 1987; Rahardjo, dkk, 1995) menyebutkan bahwa hubungan stratigrafi antara batuan vulkanik di Kubah Kulon Progo dan satuan batugamping terutama Formasi Sentolo yang berada di atasnya adalah tidak selaras. Penelitian ini menemukan kontak langsung secara selaras dan menjemari antara breksi vulkanik dan batugamping berlapis Sentolo. Oleh sebab itu hal ini menjadi koreksi atau pengayaan khasanan ilmu pengetahuan atas hubungan stratigrafi antara kedua formasi.
\end{abstract}

Kata Kunci : batuan vulkanik; batugamping berlapis Sentolo; hubungan stratigrafi; menjemari.

\section{ABSTRACT}

Physiography of the Central Java was divided by Van Bemmelen (1949) into six zones; they are Alluvial Plain of North Java, North Serayu Anticlinorium, Dome and Ridge on the Central Depression Zone, Central Depression Zone with Quaternary Volcanoes, and Southern Mountains. The Wonotopo and its surrounding area belong to the Kulon Progo Dome. Lithostratigraphy of this area from the oldest to the youngest is Nanggulan Formation, Kaligesing Formation, Dukuh Formation, Jonggrangan Formation, Sentolo Formation and Quaternary volcanic and alluvial deposits, respectively. In general, the previous researchers such as Van Bemmelen (1949), Pringgoprawiro \& Riyanto (1987), and Rahardjo, et al., (1995) mentioned that the stratigraphic relationship between volcanic rocks in Kulon Progo Dome and the limestone units especially for Sentolo Formation is unconformity. This study found such straight contacts between the volcanic breccia and Sentolo limestones as conformity and interfingering relationships. Therefore it was to become a correction or scientific insight enrichment on the stratigraphic correlation between the two formations.

Keywords: bedded limestone of Sentolo; inter-fingering volcanic rocks; stratigraphic relationship.

\section{PENDAHULUAN}

Zona Kulon Progo yang berada di dalam lingkup Zona Depresi Tengah Jawa Tengah (Van Bemmelen, 1949) disusun oleh litostratigrafi dengan lingkungan pengendapan bervariasi mulai dari laut hingga darat. Berbagai penelitian geologi telah dilaksanakan di daerah ini, baik tentang geologi secara umum, stratigrafi, struktur geologi, geologi teknik, maupun geologi lingkungan dan kebencanaan. Sebagian besar hasil penelitian-penelitian geologi yang pernah dilakukan menyebutkan bahwa hubungan stratigrafis antara batuan vulkanik yang terdiri dari breksi, lava dan intrusi, terhadap batugamping yang berada di atasnya adalah tidak selaras.

Di dalam penelitian ini telah dilakukan pemetaan geologi, pengamatan dan analisis stratigrafi terukur secara detail guna menentukan serta memberikan koreksi terhadap hubungan stratigrafi antara breksi vulkanik dan batugamping Sentolo di Zona Kulon Progo. Adapun lokasi penelitian berada di Daerah Wonotopo, Kecamatan Gebang, Kabupaten Purworejo, Jawa Tengah yang dapat dilihat pada Gambar 1. 


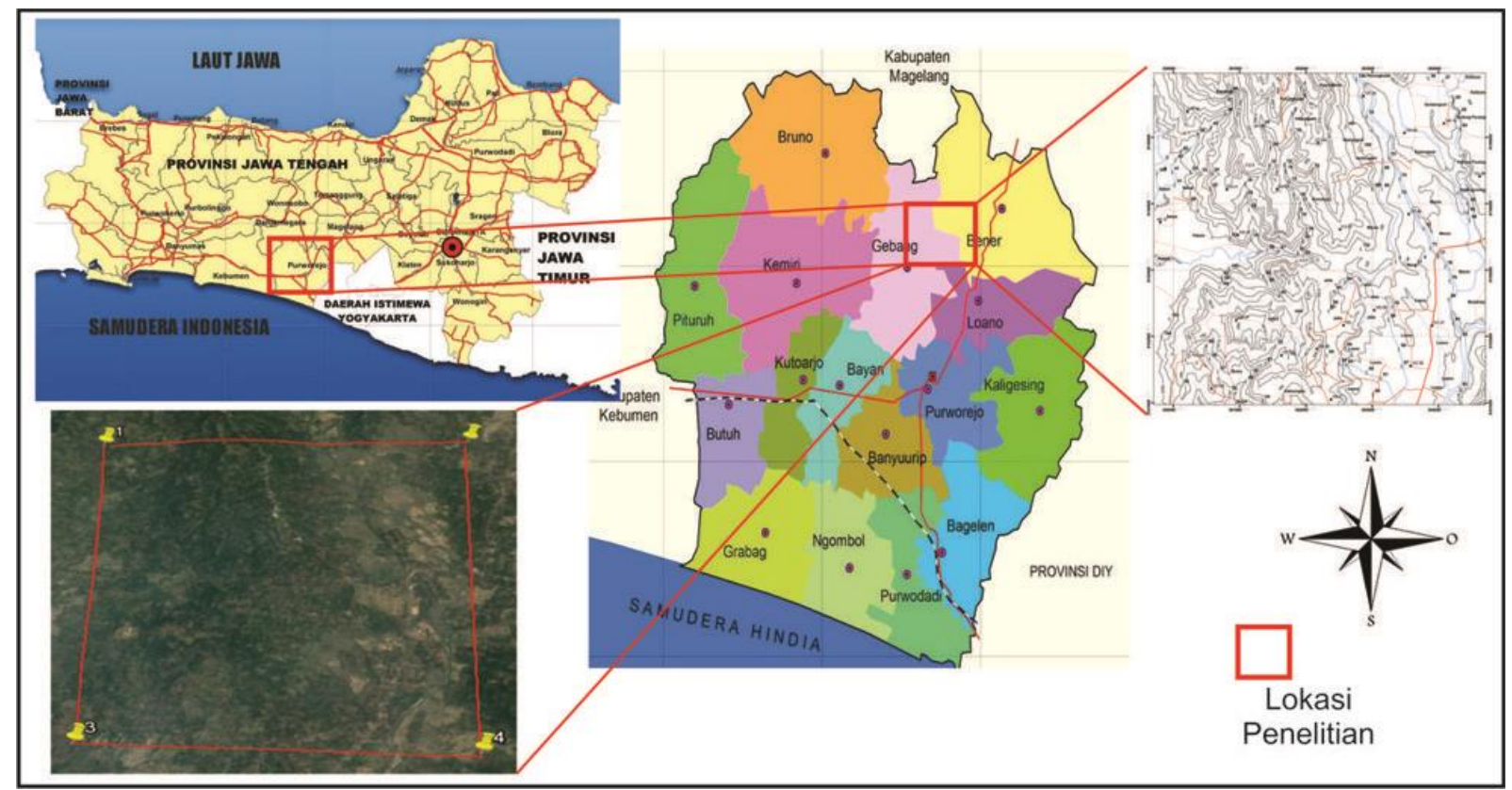

Gambar 1. Lokasi Penelitian, berada di wilayah Kecamatan Gebang, Kabupaten Purworejo

\section{METODE PENELITIAN DAN TINJAUAN PUSTAKA}

\subsection{Metode Penelitian}

Metode yang diterapkan dalam penelitian ini adalah komparatif dan analitik, dengan melakukan pemetaan geologi serta analisis stratigrafi terukur. Pemetaan geologi dilaksanakan secara observasi lapangan menggunakan jalur lintasan tersistem, pengamatan bentuklahan dan singkapan, serta pengukuran kedudukan batuan serta struktur geologi. Selain pekerjaan lapangan, dilakukan pula penelitian di laboratorium terhadap contoh-contoh batuan terpilih sehingga dapat mewakili kondisi geologi khususnya stratigrafi di daerah penelitian. Adapun penelitian laboratorium yang dilaksanakan adalah analisis petrologi dan analisis petrografi untuk menentukan baik jenis maupun nama batuan, serta analisis paleontologi guna menentukan umur relatif batuan serta lingkungan batimetriknya.

\subsection{Tinjauan Pustaka}

Terkait dengan fisiografi daerah penelitian, Van Bemmelen (1949) membagi Jawa Tengah menjadi enam zona, yaitu Gunung Api Kuarter, Dataran Aluvial Utara Jawa, Antiklinorium Serayu Utara, Kubah dan Punggungan pada Zona Depresi Tengah, Zona Depresi Tengah dan Pegunungan Selatan. Berdasarkan pembagian tersebut maka daerah Kulon Progo termasuk bagian Kubah dan Punggungan pada Zona Depresi Tengah, dan selanjutnya disebut sebagai Kubah Kulon Progo yang dapat dilihat pada Gambar 2.

Daerah Yogyakarta terutama bagian Baratdaya Kubah Kulon Progo, menurut Sujanto dan Roskamil (1977) (dalam Haryanto, 2008) merupakan daerah perbukitan, berada di poros pematang pada Zona Depresi Jawa bagian tengah. Di dalam poros pematang tersebut terdapat sejumlah tinggian, mulai dari Barat ke Timur yaitu Tinggian Gabon, Tinggian Karangbolong, Tinggian Kebumen, Tinggian Kulon Progo, dan Tinggian Besuki. Tinggian-tinggian tersebut pada umumnya dibatasi oleh lembah-lembah yang mencerminkan kehadiran sesarsesar bongkah dengan throw relatif besar (Harjanto, 2008).

Secara regional satuan litostratigrafi mulai dari yang tua ke muda terdiri dari Formasi Nanggulan, Formasi Kaligesing, Formasi Dukuh, Formasi Jonggrangan, Formasi Sentolo serta endapan gunung api Kuarter dan endapan aluvial. Menurut Hartono \& Sudrajat (2017), Formasi Nanggulan merupakan formasi tertua di daerah Kulon Progo. Formasi tersebut diberi nama sebagai Nanggulan beds (Purnamaningsih dan Pringgoprawiro, 1981; Pringgoprawiro \& Riyanto, 1987). Hartono, 1969 (dalam Harjanto, 2008) menyebutkan sebagai Globigerina marl untuk lapisan paling atas Formasi Nanggulan, yang selanjutnya oleh Purnamaningsih dan Pringgoprawiro (1981) dijadikan sebuah satuan stratigrafi, yakni Anggota Seputih. Formasi Nanggulan dicirikan oleh kehadiran batupasir bersisipan lignit, batulempung disertai konkresi limonit, napal, batupasir dan tufa. Berdasarkan kehadiran fosil-fosil foraminifera plangton, umur Formasi Nanggulan dapat ditentukan yaitu Eosen Tengah sampai Oligosen Awal (Hartono \& Sudrajat, 2017). 

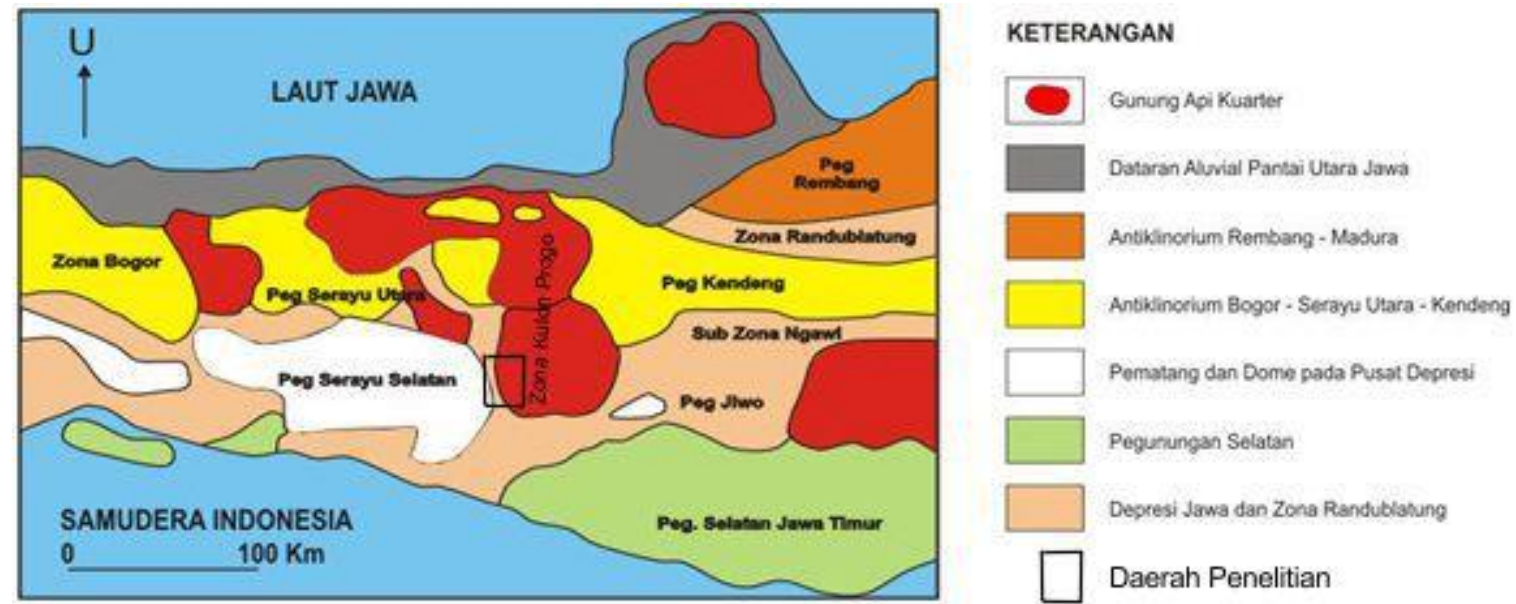

Gambar 2. Pembagian Zona Fisiografi Jawa Tengah oleh Van Bemmelen (1949)

Di atas Formasi Nanggulan didapatkan Formasi Andesit Tua (Van Bemmelen, 1949). Pringgoprawiro dan Riyanto (1987) mengubah penamaan Formasi Andesit Tua menjadi dua formasi yaitu Formasi Kaligesing dan Formasi Dukuh. Formasi Kaligesing dicirikan oleh breksi monomiks, dengan fragmen andesit, sisipan batupasir dan lava andesit. Sastroprawiro \& Santoso (1987) dalam Hartono \& Sudrajat (2017) memberi nama formasi ini sebagai Formasi Kulon Progo. Sedangkan Formasi Dukuh terdiri dari breksi polimiks dengan fragmen-fragmen berupa andesit, batupasir, dan batugamping. Di sisi lain Sastroprawiro \& Santoso (1987) dalam Hartono \& Sudrajat menamakannya Formasi Giripurwo. Umur formasi tersebut adalah Oligosen Akhir hingga Miosen Awal. Ketebalan breksi vulkanik di Kubah Kulon Progo menurut Raharjo, et.al. (1977) adalah lebih dari 600 meter, sementara itu umurnya adalah Oligosen Akhir.

Menurut Van Bemmelen (1949), Suyanto \& Roskamil (1975) dalam Hartono \& Sudrajat (2017), serta Raharjo et.al. (1995), secara tidak selaras di atas Formasi Andesit Tua diendapkan Formasi Jonggrangan dan Formasi Sentolo. Sastroprawiro \& Santoso (1987) dalam Hartono \& Sudrajat (2017) menyebutkan bahwa setelah pengendapan Formasi Kulon Progo, diendapkan Formasi Giripurwo secara selaras. Selanjutnya di atas Formasi Giripurwo terdapat Formasi Jonggrangan dan Formasi sentolo, namun tidak disebutkan secara tegas bagaimana hubungan stratigrafisnya. Ciri litologi Formasi Jonggrangan adalah napal tufaan dan batupasir gampingan dengan sisipan lignit. Litofasies Formasi Jonggrangan di bagian atas berubah menjadi batugamping berlapis dan batugamping terumbu. Di sisi lain, Formasi Sentolo bagian bawah tersusun oleh perselingan batulempung dan batupasir. Kemudian di bagian atas terjadi perubahan menjadi napal dengan sisipan batupasir dan tuf. Di atas Formasi Sentolo dijumpai endapan vulkanik Kuarter secara tidak selaras. Endapan tersebut merupakan hasil letusan Gunung Merapi, terdiri dari tufa, tufa lapilli, pasir tufaan, breksi, aglomerat dan lava andesit.

Kegiatan magmatisme di daerah Kulon Progo berlangsung pada kala Oligosen hingga Miosen (Van Bemmelen, 1949) dengan arah penyebaran batuan vulkanik Barat - Timur. Sepanjang jaman Tersier, diduga daerah Kulon Progo telah mengalami deformasi, paling sedikit dua kali periode tektonik (Sopaheluwakan, 1994, dalam Soeria Atmadja, et.al. 1991; dan Harjanto, 2008). Periode tektonik pertama terjadi pada Oligosen Akhir - Miosen Awal dan periode kedua terjadi pada Miosen Tengah - Miosen Akhir, menghasilkan busur magmatik. Peta geologi Daerah Kulon Progo dapat dilihat pada Gambar 3, sedangkan korelasi stratigrafi dari berbagai peneliti terdapat di Gambar 4.

\section{HASIL DAN PEMBAHASAN}

\subsection{Geomorfologi}

Daerah Wonotopo, Kecamatan Gebang, merujuk pada klasifikasi Van Zuidam (1983) menunjukkan bentuklahan bervariasi, yaitu Punggungan Vulkanik (V1), Perbukitan Vulkanik (V2), Dataran Vulkanik Terdenudasi (V3), Lembah Homoklin (S1), Dataran Aluvial (F1), dan Tubuh Sungai (F2). Diskripsi pembagian bentuklahan di daerah penelitian dapat dilihat pada Tabel 1.

\section{a. Struktur Geologi}

Dilacak dari citra SRTM, daerah Wonotopo dan sekitarnya menunjukkan pola-pola kelurusan dibentuk oleh alur-alur lembah sungai, poros perbukitan serta punggungan, dengan arah umum Baratlaut-Tenggara. Arah umum kelurusan tersebut berkorelasi dengan arah utama kekar-kekar yang terdapat pada singkapan-singkapan 

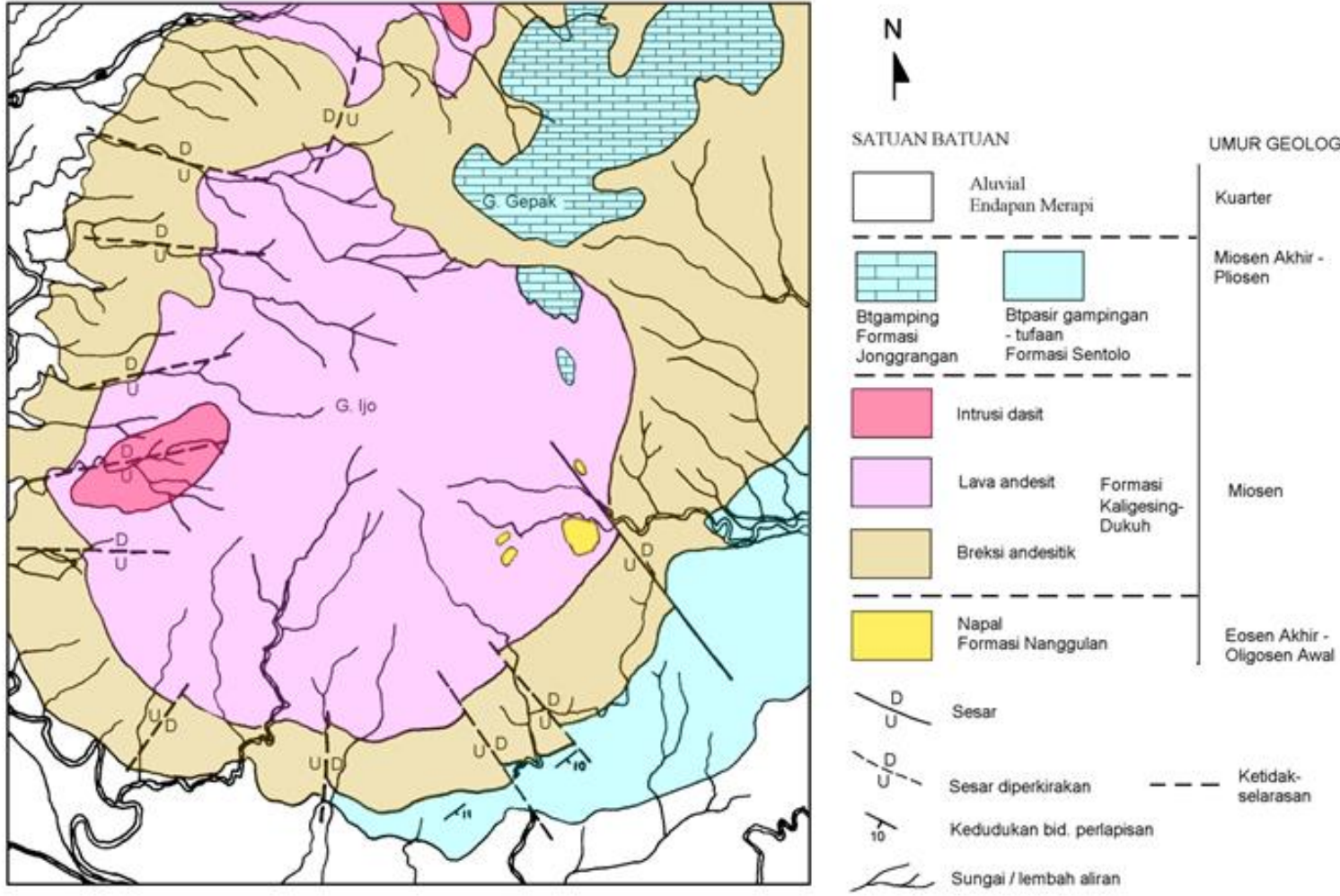

Gambar 3. Peta Geologi Daerah Kulon Progo (Rahardjo, et.al. 1977, modifikasi oleh Kusumayudha, 2006, 2009, 2010)

batuan. Struktur kekar di daerah penelitian berkembang secara sistematis dengan jenis kekar gerus yang berpasangan. Hasil analisis kekar dengan menggunakan diagram roset menunjukkan arah tegasan umum pada daerah penelitian yaitu relatif Baratlaut - Tenggara.

Kedudukan perlapisan batuan yang terdapat di daerah Wonotopo dan sekitarnya pada umumnya memiliki kemiringan ke arah Timur sampai Tenggara. Kedudukan perlapisan batuan tersebut merepresentasikan kemiringan struktur homoklinal dengan arah jurus sekitar Utara sampai Timurlaut.

Struktur kekar dan sesar di daerah Wonotopo berkembang menunjukkan pola sistematis dan memiliki jurus dengan arah umum Baratlaut - Tenggara. Demikian pula pola kelurusan lembah dan struktur sesar berdasarkan interpretasi citra SRTM memperlihatkan arah-arah umum Baratlaut - Tenggara. Selaras dengan hal tersebut, struktur sesar di daerah penelitian juga mempunyai jurus Baratlaut - Tenggara, berupa sesar mendatar dengan pergerakan relatif ke kanan (dekstral). Peta geologi daerah Wonotopo dan sekitarnya disajikan pada Gambar 5.

\section{Breksi Vulkanik}

Satuan batuan breksi vulkanik di Perbukitan Kulon Progo memiliki beberapa nama. Van Bemmelen (1949) memberi nama Old Andesite Formation, Raharjo, et.al. (1977), menyebutnya sebagai Formasi Kebobutak, Sastroprawiro \& Santoso memberi nama Formasi Kulon Progo (breksi vulkani bagian bawah) dan Formasi Giripurwo, sementara itu Pringgoprawiro dan Riyanto (1987) memberi nama Formasi Kaligesing dan Formasi Dukuh. 
JMEL, Volume 3 Nomor 1, 2019

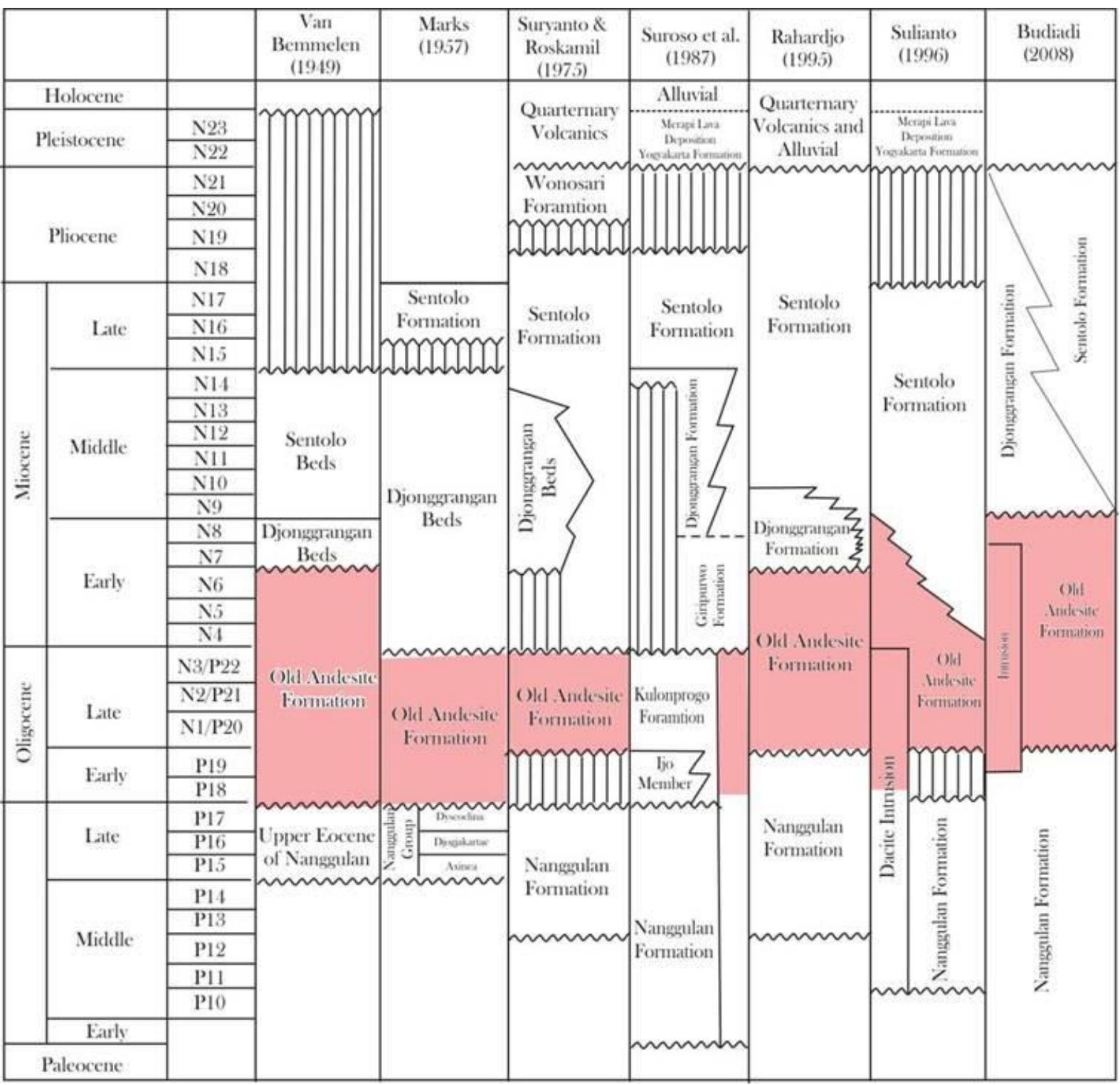

Gambar 4. Korelasi Stratigrafi Daerah Kulon Progo dari Berbagai Peneliti (Hartono \& Sudrajat, 2017)

Breksi vulkanik yang dijumpai di daerah Wonotopo, pada bagian bawah tersusun oleh fragmen-fragmen dan matriks berupa batuan andesit, sedangkan semen berupa silika, terpilah buruk, struktur sedimen massif. Batuan ini menunjukkan karakteristik sebagaimana breksi pada Formasi Kaligesing (Pringgoprawiro \& Riyanto, 1987). Di bagian atas, selain fragmen andesit, di dalam breksi vulkanik terdapat pula fragmen batugamping dan cangkang biota laut, dengan semen karbonatan. Ukuran fragmen relatif lebih kecil dibandingkan dengan breksi yang berada di bagian bawah. Pada bagian ini dapat diamati struktur sedimen graded bedding meskipun tidak ideal. Komposisi matriks menunjukkan karbonatan. Hal ini mengindikasikan bahwa lingkungan pengendapan breksi vulkanik bagian atas ini berupa laut. Ciri-ciri litofasies seperti ini menunjukkan kemiripan dengan Formasi Dukuh (Pringgoprawiro \& Riyanto, 1987).

Di daerah Wonotopo, antara breksi Formasi Kaligesing dan breksi Formasi Dukuh sulit dipisahkan secara tegas. Batas-batas satuan batuan atau formasi berubah secara gradual, sehingga sulit ditarik perbatasannya. Oleh karena itu di dalam penelitian ini, satuan breksi vulkanik disatukan penyebutannya sebagai Formasi Kaligesing Dukuh. 
Tabel 1. Deskripsi Pembagian Satuan Bentuklahan Daerah Wonotopo dan Sekitarnya.

\begin{tabular}{|c|c|c|c|}
\hline $\begin{array}{c}\text { Satuan } \\
\text { Bentuklahan }\end{array}$ & Diskripsi & $\begin{array}{l}\text { Material } \\
\text { Penyusun }\end{array}$ & $\begin{array}{c}\text { Morfostruktur \& } \\
\text { Pola Aliran yang } \\
\text { Berkembang }\end{array}$ \\
\hline $\begin{array}{l}\text { Punggungan } \\
\text { Vulkanik } \\
\text { (V1) }\end{array}$ & $\begin{array}{c}\text { Menempati } 25 \% \text { dari luas daerah } \\
\text { penelitian, berada di bagian Utara, } \\
\text { topografi bergelombang, sudut lereng } \\
16^{\circ}-35^{\circ}(30 \%-70 \%)\end{array}$ & $\begin{array}{l}\text { breksi vulkanik } \\
\text { dengan resistensi } \\
\text { batuan kuat }\end{array}$ & $\begin{array}{l}\text { pengangkatan dan } \\
\text { kekar, dikontrol pola } \\
\text { aliran rektangular }\end{array}$ \\
\hline $\begin{array}{l}\text { Perbukitan } \\
\text { Vulkanik } \\
\text { (V2) }\end{array}$ & $\begin{array}{c}\text { Menempati } 15 \% \text { dari luas daerah } \\
\text { penelitian, berada di Baratdaya, } \\
\text { topografi bergelombang, kemiringan } \\
8^{0}-35^{0}(30 \%-70 \%)\end{array}$ & $\begin{array}{l}\text { breksi vulkanik } \\
\text { dengan resistensi } \\
\text { batuan kuat }\end{array}$ & $\begin{array}{l}\text { pengangkatan, pola } \\
\text { aliran rektangular dan } \\
\text { subdenritik }\end{array}$ \\
\hline $\begin{array}{l}\text { Dataran } \\
\text { Vulkanik } \\
\text { (V3) }\end{array}$ & $\begin{array}{l}\text { Menempati } 30 \% \text { terhadap luas daerah } \\
\text { penelitian, berada di Timur, topografi } \\
\text { datar hingga agak miring, sudut lereng } \\
0^{0}-4^{0}(0 \%-7 \%)\end{array}$ & $\begin{array}{l}\text { breksi vulkanik } \\
\text { dengan resistensi } \\
\text { batuan kuat. }\end{array}$ & $\begin{array}{l}\text { pengangkatan, dan } \\
\text { pola aliran denritik }\end{array}$ \\
\hline $\begin{array}{l}\text { Lembah } \\
\text { Struktural } \\
\quad(\text { S1) }\end{array}$ & $\begin{array}{l}\text { Menempati sekitar } 20 \% \text { dari luas } \\
\text { daerah penelitian, berada di Baratlaut, } \\
\text { topografi berupa lembah dan } \\
\text { berlereng miring } 6 \%-13 \%\end{array}$ & $\begin{array}{l}\text { batugamping } \\
\text { berlapis dengan } \\
\text { resistensi sedang } \\
\text { hingga lemah. }\end{array}$ & $\begin{array}{l}\text { pensesaran dan kekar- } \\
\text { kekar, pola pengaliran } \\
\text { rektngular dan } \\
\text { subdenritik }\end{array}$ \\
\hline $\begin{array}{c}\text { Dataran } \\
\text { alluvial (F1) }\end{array}$ & $\begin{array}{c}\text { Menempati } 7 \% \text { dari luas daerah } \\
\text { penelitian, di bagian Barat, morfologi } \\
\text { berupa dataran, kemiringan landai } \\
(3 \%-7 \%)\end{array}$ & $\begin{array}{l}\text { lumpur dan } \\
\text { material lepas } \\
\text { lainnya }\end{array}$ & $\begin{array}{l}\text { sedimentasi material } \\
\text { lepas, pelapukan dan } \\
\text { erosi. }\end{array}$ \\
\hline $\begin{array}{c}\text { Tubuh } \\
\text { Sungai (F2) }\end{array}$ & $\begin{array}{l}\text { Menempati } 3 \% \text { dari luas daerah } \\
\text { penelitian, kedalaman sekitar } 7 \text { meter, } \\
\text { aliran dari Utara ke Selatan, topografi } \\
\text { datar, kemiringan } 1^{0}-2^{0}(1 \%-2 \%)\end{array}$ & $\begin{array}{l}\text { lumpur dan } \\
\text { material lepas } \\
\text { lainnya }\end{array}$ & $\begin{array}{l}\text { tidak dipengaruhi } \\
\text { oleh struktur geologi, } \\
\text { pola aliran dendritik }\end{array}$ \\
\hline
\end{tabular}

\section{Endapan Aluvial}

Endapan Aluvial merupakan satuan batuan paling muda, berupa material lepas hasil pelapukan dan erosi dari batuan yang lebih tua. Satuan ini tersusun oleh material lepas yang belum terlitifikasi (unconsolidated). Endapan aluvial terdiri dari material lepas dan berupa endapan yang belum mengalami terlitifikasi, didominasi oleh tekstur berukuran lempung dan sebagian berukuran pasir hingga bongkah. Pada litologi tersebut tidak ditemukan adanya struktur sedimen seperti halnya perlapisan. Hubungan stratigrafi endapan alluvial dengan satuan batuan di awahnya merupakan ketidakselarasan ditandai dengan adanya bidang erosi.

\section{b. Hubungan Stratigrafi antara Breksi Vulkanik dan Batugamping}

Pada saat dilakukan pemetaan geologi daerah Wonotopo dan sekitarnya, di beberapa lokasi pengamatan dijumpai kontak langsung antara breksi vulkanik bagian atas dengan batugamping berlapis yang menumpang di atasnya. Pada daerah tersebut dijumpai pula adanya perlapisan berulang antara breksi vulkanik dan batugamping berlapis, sebagaimana ditunjukkan pada hasil pengukuran stratigrafi detail (Measuring Section $=$ MS). Di bagian kontak antara breksi dan batugamping berlapis, tidak terdapat gejala-gejala ketidakselarasan, tidak dijumpai adanya bidang erosi, basal konglomerat, ataupun soil purba.

Berdasarkan atas dijumpainya kontak langsung breksi dan batugamping, terdapatnya perulangan perlapisan batugamping dan breksi vulkanik, sebagaimana diperkuat dari hasil stratigrafi terukur yang dapat dilihat pada Gambar 6, maka dapat disimpulkan bahwa hubungan stratigrafis antara Formasi Sentolo dengan breksi vulkanik Formasi Kaligesing - Dukuh adalah menjemari (interfingering). 


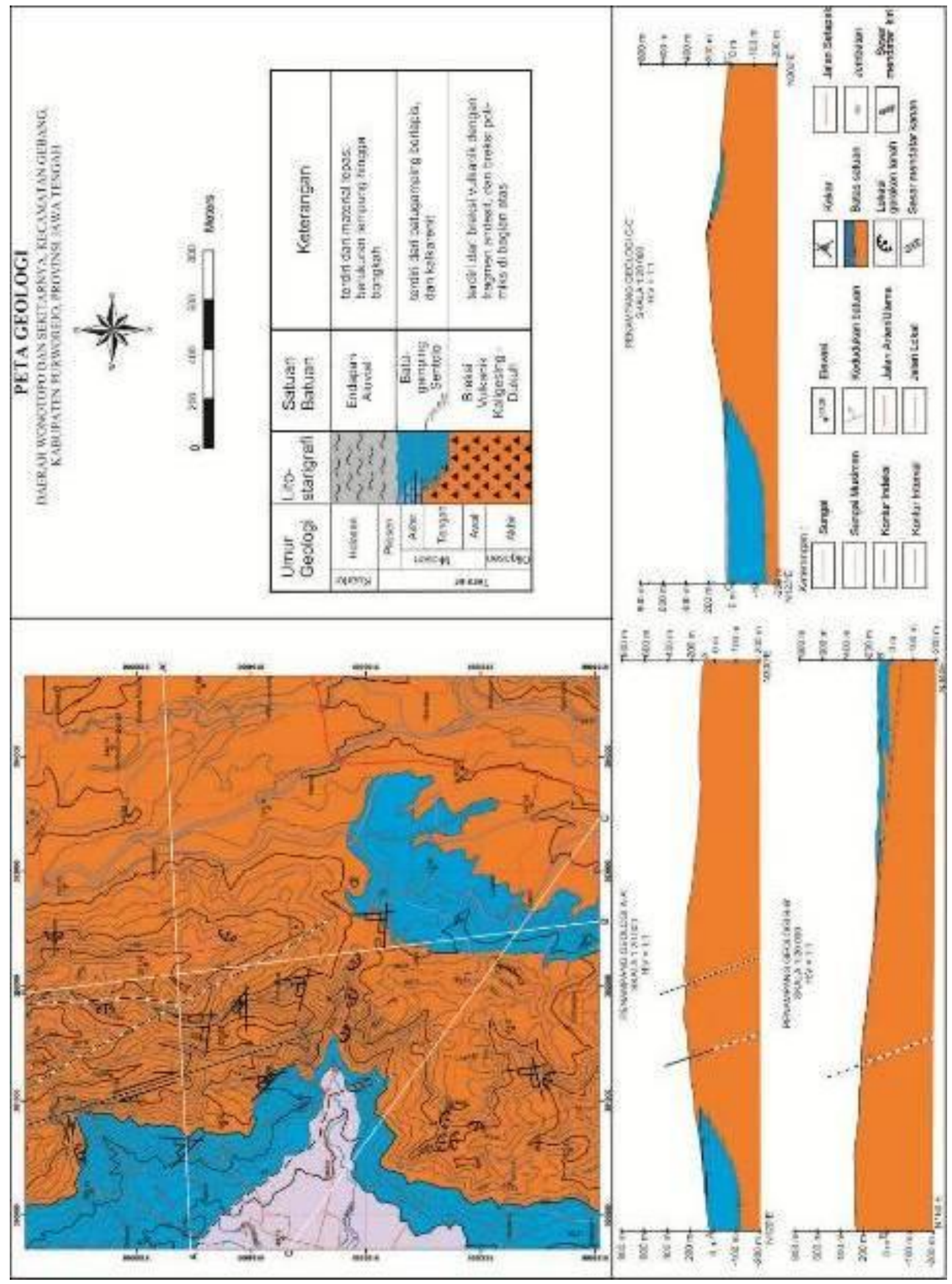

Gambar 5. Peta Geologi Daerah Wonotopo, Kecamatan Gebang, Kabupaten Purworejo 

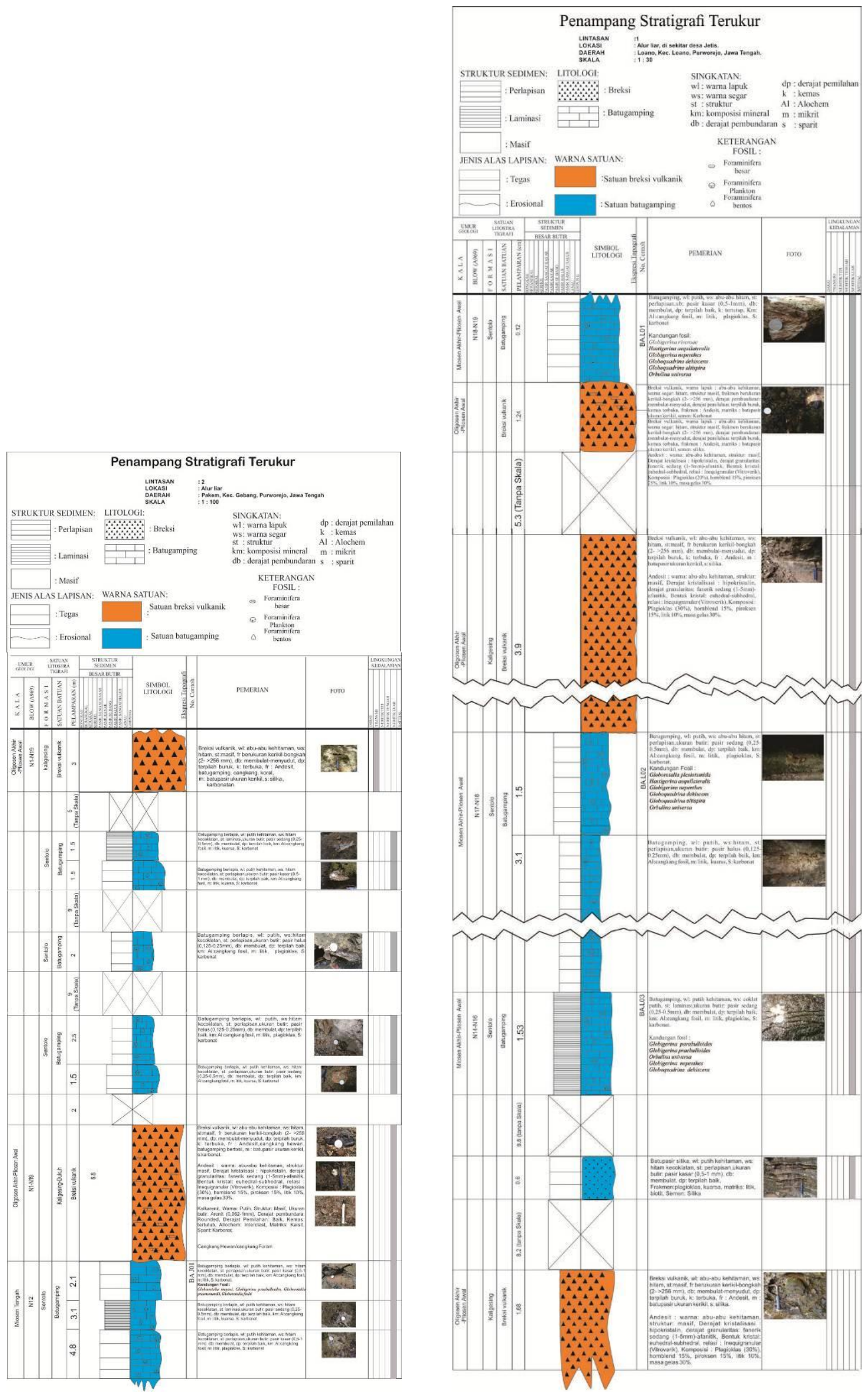

Gambar 6. Kolom Stratigrafi Terkukur di dusun Pakem (kiri) dan di dusun Loano (kanan) 
Tabel 2. Analisis Paleontologi Satuan Batugamping Formasi Sentolo berturut-turut bagian bawah, bagian tengah, dan bagian atas

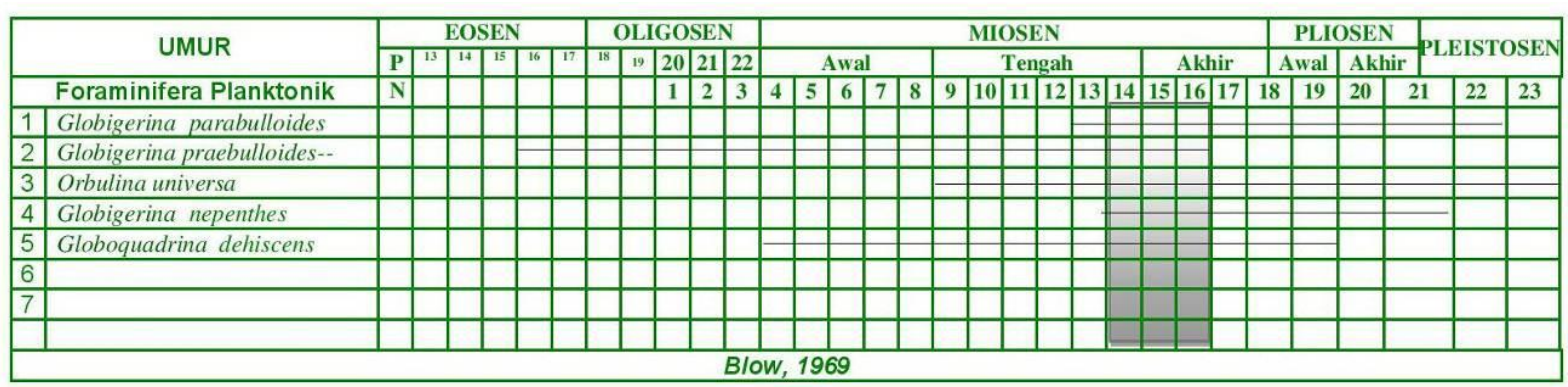

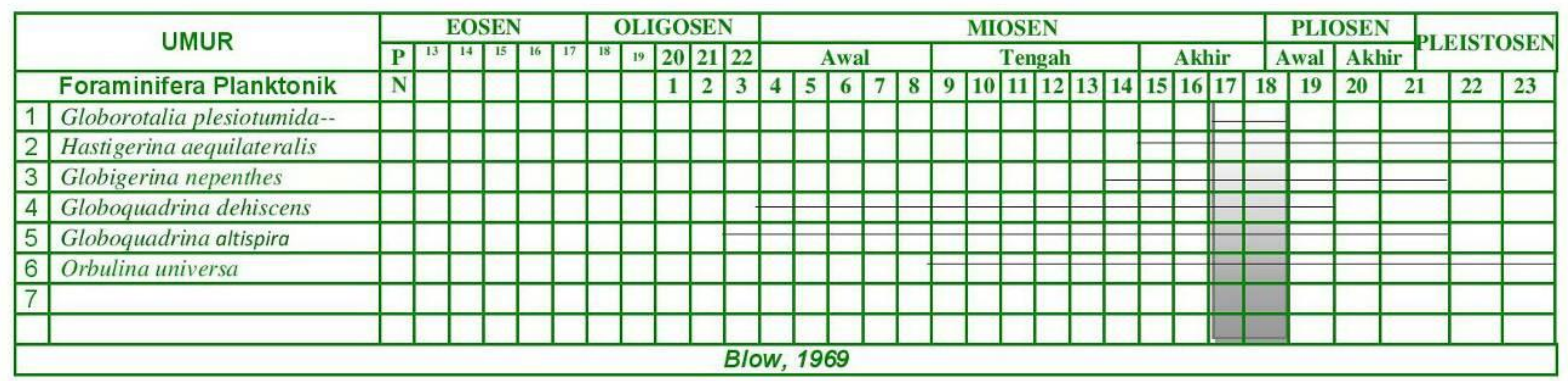

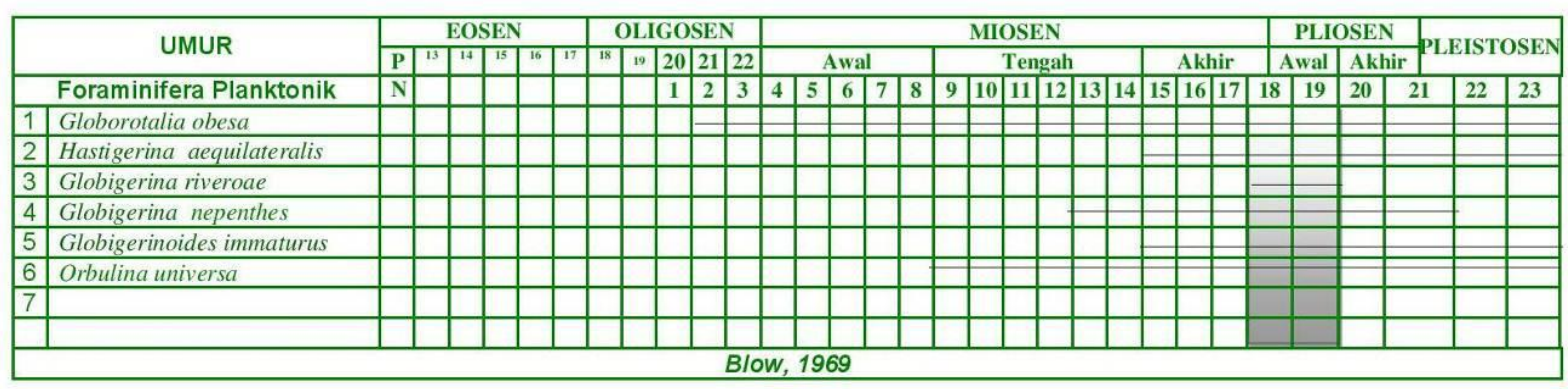

Tabel 3. Analisis paleontologi batugamping yang menyisip pada breksi vulkanik bagian atas

\begin{tabular}{|c|c|c|c|c|c|c|c|c|c|c|c|c|c|c|c|c|c|c|c|c|c|c|c|c|c|c|c|c|c|c|}
\hline \multirow{2}{*}{\multicolumn{2}{|c|}{ UMUR }} & \multicolumn{4}{|c|}{ EOSEN } & \multicolumn{5}{|c|}{ OLIGOSEN } & \multicolumn{14}{|c|}{ MIOSEN } & \multicolumn{4}{|c|}{ PLIOSEN } & & \\
\hline & & \multirow{2}{*}{\begin{tabular}{l|l}
$\mathbf{P}$ & \\
$\mathbf{N}$ & \\
\end{tabular}} & \multirow{2}{*}{\begin{tabular}{|l|l|}
13 & 14 \\
& \\
\end{tabular}} & \multirow{2}{*}{${ }^{15}$} & \multirow[t]{2}{*}{\begin{tabular}{|l|l|}
16 \\
\end{tabular}} & \multirow{2}{*}{\begin{tabular}{l|l}
17 & 18 \\
& \\
\end{tabular}} & \multirow{2}{*}{\begin{tabular}{l|l|}
18 & 19 \\
& \\
\end{tabular}} & \multirow{2}{*}{\begin{tabular}{|c|}
20 \\
1 \\
\end{tabular}} & \multirow{2}{*}{\begin{tabular}{|l|l|}
21 & \\
2 & \\
\end{tabular}} & \multirow{2}{*}{22} & \multicolumn{5}{|c|}{ Awal } & \multicolumn{6}{|c|}{ Tengah } & \multicolumn{3}{|c|}{ Akhir } & \multicolumn{2}{|c|}{ Awal } & Akhir & & & \\
\hline & Foraminifera Planktonik & & & & & & & & & & \begin{tabular}{|l|l|}
4 & \\
\end{tabular} & 5 & \begin{tabular}{|l|l|}
6 & \\
\end{tabular} & 7 & 8 & 9 & 10 & 11 & 12 & 13 & 14 & 15 & 16 & 17 & 18 & 19 & 20 & 21 & 22 & 23 \\
\hline 1 & Globorotalia obesa & & & & & & & & & & & & & - & - & & & & 4 & + & - & & - & E & - & - & - & & 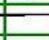 & \\
\hline 2 & Orbulina universa & & & & & & & & & & & & & & & - & & - & 4 & $\square$ & E & Z & 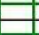 & $\square$ & - & & & & & \\
\hline 3 & Globorotalia mayeri & & & & & & & & & & & & & & & - & - & - & 27 & $\theta$ & & & & & & & & & & \\
\hline 4 & Globigerina praebulloides & & & & & & - & & - & - & - & - & - & - & - & 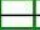 & E & 田 & 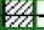 & $\square$ & E & E & $\square$ & & & & & & & \\
\hline 5 & Globorotalia praemenardii & & & & & & & & & & & & & & & & & 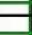 & m & $\theta$ & & & & & & & & & & \\
\hline 6 & Globorotalia foshi & & & & & & & & & & & & & & & & & & m & & & & & & & & & & & \\
\hline 7 & & & & & & & & & & & & & & & & & & & & & & & & & & & & & & \\
\hline & & & & & & & & & & & & & & & & & & & & & & & & & & & & & & \\
\hline & & & & & & & & & & $B / 0$ & $w$, & 19 & & & & & & & & & & & & & & & & & & \\
\hline
\end{tabular}

\section{KESIMPULAN}

Berdasarkan hasil pemetaan geologi dan analisis stratigrafi terukur secara detail yang dilakukan di daerah Wonotopo dan sekitarnya, maka dapat disimpulkan sebagai berikut:

1. Geologi Daerah Wonotopo dan sekitarnya disusun oleh berbagai variasi litologi. Bagian paling bawah terdiri dari breksi vulkanik monomiks dengan fragmen-fragmen andesit, serta breksi vulkanik polimiks dengan fragmen-fragmen andesit, batupasir dan batugamping. Breksi vulkanik termasuk ke dalam Formasi Kaligesing - Dukuh, berumur Oligosen - Miosen Tengah. Di atas breksi vulkanik terdapat batugamping berlapis dan kalkarenit, termasuk Formasi Sentolo, berumur Miosen Tengah - Pliosen (N12 - N19). Di bagian paling atas terdapat Endapan Aluvial berumur Kuarter. Struktur geologi yang terdapat di Daerah Wonotopo berupa kekar dan sesar. Sesar termasuk klasifikasi sesar mendatar dekstral.

2. Hubungan stratigrafis antara Formasi Sentolo bagian bawah dan breksi vulkanik Formasi Kaligesing Dukuh bagian atas adalah menjemari (interfingering). Hal ini dibuktikan dengan dijumpainya kontak selaras 
3. serta perselang-selingan perlapisan antara breksi vulkanik dengan batugamping berlapis dan kalkarenit Formasi Sentolo di daerah Wonotopo.

4. Ditemukannya hubungan stratigrafis menjemari (interfingering) antara breksi vulkanik dengan batugamping di Daerah Wonotopo sekaligus mengoreksi dan memperkaya khasanan ilmu pengetahuan terhadap geologi pada umumnya dan stratigrafi daerah Kulon Progo pada khususnya, sehingga menjadi referensi bagi penelitian-penelitian geologi berikutnya.

\section{DAFTAR PUSTAKA}

Blow, W.H. (1969). Late Middle Miocene to Recent Planktonic Foraminiferal Biostratigraphy, Proceedings First Internasional Conference on Planktonic Microfossil.Geneva, 1967(1), 119-442

Exploration of spring using fractal analysis in the Kulonprogo volcanic aquifer. (2009). Yogyakarta Special Province, Indonesia. Prosiding International Association of Hydrogeology Congress. India: Hyderabad.

Harjanto, A. (2008). Vulkanostratigrafi di Daerah Kulon Progo dan sekitarnya, Daerah Istimewa Yogyakarta. Jurnal Ilmiah Magister Teknik Geologi, Vol : 4, Nomor 8: 30 - 45.

Hartono, H.G \& Sudrajat, A. (2017). Nanggulan formation and its problem as a basement in Kulonprogo basin, Yogyakarta. Indonesian Journal on Geoscience, Vol. 4 No. 2 August 2017: 71-80

Kusumayudha, S.B. (2006). The application of fractal geometry for slope stability. Case Study: Kulonprogo Area. Jurnal Natur Indonesia, Universitas Riau.

Model konseptual hidrogeologi kubah Kulonprogo berdasarkan pemetaan dan analisis geometri fraktal. (2010). Pros Pertemuan Ilmiah Tahunan Ikatan Ahli Geologi Indonesia (IAGI) XXXIX. Lombok: paper No. 104.

Pringgoprawiro, H., dan Riyanto, B.. (1987). Formasi andesit tua suatu revisi. Pros, Pertemuan Ilmiah Tahunan Ikatan Ahli Geologi Indonesia (IAGI) XVI. Bandung.

Purnamaningsih, S. dan Pringgoprawiro, H., (1981). Stratigraphy and planktonic foraminifera of the eoceneoligocene nanggulan formation, Central Java. Geol. Res. Dev. Centre Pal. Ser. Bandung, Indonesia. No.1: 9 - 28.

Rahardjo, W., Sukandarrumidi, \& Rosidi, H.M.S. (1977). Peta geologi lembar Yogyakarta skala 1:100.000. Bandung: Direktorat Geologi.

Rahardjo, W., Sukandarrumidi, \& Rosidi, H.M.S. (1995). Peta geologi lembar Yogyakarta skala 1:100.000. Bandung: Direktorat Geologi.

Soeria Atmadja, R., Maury, R.C., Suparka, E., Yuwono, S. (1991). Petrologi dan geokimia batuan vulkanik. Pros. Pertemuan Ilmiah Ikatan Ahli Geologi Indonesia (IAGI) XX, Bandung.

Van Bemmelen R.W. (1949). The geology of Indonesia. The Haque Martinus Nijnhoff, Vol IA (653 - 732). 